\title{
PENGARUH PENGETAHUAN DAN SIKAP KEPADA LINGKUNGAN TERHADAP NIAT MENGINAP DI HOTEL RAMAH LINGKUNGAN
}

\author{
Ida Ayu Kalpikawati \\ Program Studi Bisnis Hospitaliti, Sekolah Tinggi Pariwisata Nusa Dua Bali, idakalpika@yahoo.com
}

\begin{abstract}
ABSTRAK
Penelitian ini bertujuan untuk mendeskripsikan pengaruh pengetahuan dan sikap kepada lingkungan terhadap niat menginap di hotel ramah lingkungan. Penelitian ini menggunakan 90 responden menggunakan kuesioner sebagai instrumen pengumpul data. Responden merupakan wisatawan yang mengetahui tentang hotel ramah lingkungan. Data dianalisis menggunakan metode statistik regresi linear berganda, selanjutnya data diolah menggunakan bantuan software IBM SPSS statistic 20. Hasil penelitian menunjukkan (1) Pengetahuan berpengaruh positif dan signifikan terhadap niat menginap di hotel ramah lingkungan, (2) Sikap kepada lingkungan berpengaruh positif dan signifikan terhadap niat menginap di hotel ramah lingkungan, (3) Pengetahuan dan sikap kepada lingkungan berpengaruh positif signifikan terhadap niat menginap di hotel ramah lingkungan.
\end{abstract}

Kata kunci: pengetahuan, sikap, niat menginap, hotel ramah lingkungan

\section{ABSTRACT}

This research aims to describe the influence knowledge and attitude to the environment intention stay at eco-friendly hotel. The study taken from a sample of 90 the touristst who know about eco-friendly hotel. The data were analyzed using statistic method multiple linear regression then processed with software IBM SPSS 20. The result show (1) Knowledge have an effect on positive significant intention of stay at eco friendly hotel, (2) Attitude to the environment have an effect positive significant intention of stay at eco-friendly hotel, (3) Knowledge and attitude to the environment have an effect intention of stay at eco-friendly hotel.

Keywords: knowledge, attitude, intention of stay, eco-friendly hotel.

\section{PENDAHULUAN}

Pariwisata merupakan salah satu sektor ekonomi yang sangat penting di Indonesia. Berdasarkan data dari Kementerian Pariwisata (Kinerja Kementerian Pariwisata 2016) pada tahun 2016 sektor pariwisata merupakan penghasil devisa keempat di Indonesia setelah minyak \& gas, batubara dan kelapa sawit. Kekuatan pariwisata Indonesia tersebut selama ini bertumpu pada keunikan budaya Indonesia dan kekayaan alam lingkungan Indonesia. 


\section{National Conference of Creative Industry: \\ Sustainable Tourism Industry for Economic Development}

Universitas Bunda Mulia, Jakarta, 5-6 September 2018 e-ISSN No: 2622-7436

Kekayaan alam dan ragam etnik budaya merupakan komponen utama pariwisata Indonesia. Dalam Kebijakan Pembangunan Kepariwisataan di Indonesia tahun 2016 dari Kementerian Pariwisata disampaikan bahwa Indonesia adalah negara bahari dan merupakan Negara dengan kepulauan terbesar di dunia terdiri dari 17.504 hamparan pulau, 300 kelompok etnik adat serta keragaman budaya yang unik serta daya tarik alam, budaya dan minat khusus yang sangat besar. Melihat potensi kekayaan alam dan ragam budaya Indonesia yang sangat luar biasa ini maka Presiden Joko Widodo menempatkan sektor pariwisata sebagai salah satu sektor prioritas dalam pembangunan di Indonesia di tahun 2017.

Industri Pariwisata merupakan industri yang tidak bisa berdiri sendiri. Dalam operasionalnya industri pariwisata terdiri dari bermacam-macam produk seperti travel agent, akomodasi, restoran, bar, perusahaan transportasi, souvenir shop dan berbagai produk dari perusahaan yang ada kaitannya dengan pariwisata. Akomodasi merupakan kebutuhan utama dalam industri pariwisata. Secara umum akomodasi berarti suatu tempat yang dibutuhkan wisatawan untuk menginap ketika mereka berwisata ke suatu destinasi wisata. Akomodasi dapat berupa tempat menginap dimana seorang bisa beristirahat, makan, minum, mandi dan sebagainya.

Hotel merupakan salah satu jenis akomodasi yang menggunakan sebagian atau seluruh bangunan yang ada, hotel juga menyediakan berbagai fasililtas, makanan, minuman, ruang, kamar, restoran, olahraga, hiburan yang tersedia untuk umum dan dikelola secara komersial (Sulastiyono,2011:6)

Perkembangan Pariwisata di Indonesia telah membawa dampak positif dalam sektor perekonomian karena telah berkontribusi sebanyak $4 \%$ dari total perekonomian. Pada tahun 2019 pemerintah menargetkan sekitar $8 \%$ pertumbuhan ekonomi dari sektor Pariwisata, sehingga pemerintah menentukan target kunjungan wisatawan sebanyak 20 juta wisatawan asing (Sulis Purwanto, 2016). Target kunjungan 20 juta wisatawan di tahun 2019 tersebut menimbulkan berbagai reaksi dari kalangan akademis terutama dampaknya terhadap kelestarian lingkungan. Dengan bertambahnya jumlah kunjungan wisatawan ke Indonesia maka kualitas lingkungan akan semakin menurun. Salah satu contohnya seperti yang ditulis Sulis Purwanto, (2016) adalah perkembangan pariwisata di Cina mengalami peningkatan yang signifikan pada beberapa tahun terakhir setelah tahun 2000. Pada tahun 2009 jumlah wisatawan di Cina mencapai 126 juta wisatawan 70,3 kali lipat lebih besar dari tahun 1978 dengan total penerimaan sebesar US\$39,7 juta. hal tersebut merupakan dampak positif terhadap pertumbuhan pariwisata, namun disisi lain dampak negatifnya adalah pariwisata berdampak terhadap lingkungan biotik (seperti kualitas air, kualitas tanah, flora dan fauna) dan lingkungan sosial budaya masyarakat setempat (Linzheng Zhong, 2011 dan Ying,AN 2015; 43-44). Diperlukan suatu upaya untuk meminimalisasi dampak perkembangan pariwisata terhadap kerusakan lingkungan, dengan merubah arah pengembangan kepariwisataan dari mass tourism menuju quality tourism (pariwisata berkelanjutan). Quality tourism dianggap mampu meminimalisasi dampak negatif pariwisata terhadap lingkungan.

Untuk memenuhi kebutuhan wisatawan para investor berlomba-lomba membangun hotel untuk memenuhi kebutuhan wisatawan. Banyak hotel dibangun tanpa memperdulikan daya dukung lingkungan sehingga cenderung merusak lingkungan. Masalah kerusakan lingkungan banyak disebabkan karena aktifitas manusia dan perilaku wisatawan yang tidak memperhatikan lingkungan juga mempercepat kerusakan terhadap lingkungan tersebut. Produk hotel yang ramah lingkungan (eco-friendly hotel) semakin diminati oleh wisatawan seiring perubahan gaya hidup dan berubahnya trend 


\section{National Conference of Creative Industry: \\ Sustainable Tourism Industry for Economic Development}

Universitas Bunda Mulia, Jakarta, 5-6 September 2018 e-ISSN No: 2622-7436

wisatawan yang semakin peduli terhadap lingkungan. Hal ini menuntut pengusaha hotel untuk membuat produk yang sesuai dengan kebutuhan wisatawan yaitu dengan mengembangkan hotel yang lebih ramah lingkungan.

\section{KAJIAN PUSTAKA}

Hotel yang menawarkan konsep ramah lingkungan atau sering disebut green hotel menggunakan desain pariwisata berkelanjutan, yang mencakup keberlanjutan ekonomi dan lingkungan di masa mendatang. Menurut Triahatmojo, pengertian dari hotel ramah lingkungan adalah penginapan bertanggungjawab terhadap lingkungan yang mengikuti praktek hidup hijau (green living). Hotel ramah lingkungan (ecofriendly hotel) harus memenuhi kriteria sebagai berikut: a) Ketergantungan pada lingkungan yang alami, b) Ekologi berkelanjutan,c) Terbukti kontribusi untuk konservasi, d) Penyediaan program pelatihan lingkungan, e) Pendirian Pertimbangan budaya, e) Penyediaan pengembalian Ekonomi ke masyarakat setempat

Pengetahuan dapat didefinisikan sebagai informasi yang disimpan dalam ingatan sedangkan himpunan bagian dari informasi yang relevan dengan fungsi konsumen dipasar disebut pengetahuan konsumen (Engel, et al.,1994). Engel, et al (1994) mengemukakan bahwa pengetahuan konsumen diklasifikasikan menjadi tiga bidang umum yaitu: pengetahuan produk, pengetahuan pemakaian dan pengetahuan pembelian. Konsumen yang memiliki pengetahuan dan kesadaran tentang arti penting lingkungan sering juga disebut "green orientation" pada masa mendatang diprediksi jumlahnya akan meningkat. Konsumen yang mempunyai pengetahuan dan kesadaran tinggi terhadap lingkungan akan memilih produk-produk yang ramah lingkungan walaupun harganya relatif mahal (Calroche et al., 2001 dalam Haryadi, 2009).

Menurut Kotler dan Amstrong (2008:157) Sikap menggambarkan perasaan, penilaian, dan kecendrungan yang relatif konsisten terhadap objek atau suatu gagasan. Sikap merupakan suatu ekspresi atas perasaan seseorang yang merefleksikan kesukaan atau ketidaksukaannya terhadap suatu objek (Suprapti 2010:135). Zelezny dalam Aman, et.al.(2012) menyatakan sikap merupakan suatu tindakan yang dapat mewakili apa yang disukai dan apa yang tidak disukai konsumen. "Sikap kepedulian lingkungan berakar pada seseorang" konsep diri dan sejauh mana seorang individu memandang dirinya untuk menjadi bagian yang integral dari lingkungan alam". Dalam arti umum sikap positif, semakin kuat niat untuk melakukan perilaku, begitu sebaliknya. Konsumen yang menghargai dan perduli terhadap kelestarian alam dan lingkungan akan cenderung mengembangkan sikap positif tersebut terhadap produk dan kegiatan yang konsisten dengan nilai tersebut. Sikap yang merupakan fungsi ekspresi nilai akan mengekspresikan nilai utama dan konsep diri konsumen. Konsumen yang memiliki sikap positif dalam dampak konsumsi pada lingkungan akan cenderung mendukung inisiatif perlindungan lingkungan, mendaur ulang, dan membeli serta menggunakan produk ramah lingkungan (Sumarsono dan Giyatno, 2012).

Niat beli merupakan suatu instruksi yang timbul dari dalam diri seorang pembeli untuk melakukan pembelian terhadap suatu merek tertentu. Kotler dan Amstrong (2007: 227) memaparkan niat beli merupakan sesuatu yang mengarah memenuhi tujuan atau niat, dimana konsumen cenderung untuk membeli merek yang paling disukainya. Sedangkan Ajzen dan Fishbein (1975) dalam Lin dan Lin, (2007) mendefinisikan niat beli sebagai kecenderungan konsumen untuk memiliki produk tertentu dan telah terbukti sebagai faktor utama untuk memprediksi perilaku konsumen. 


\section{METODE PENELITIAN}

Jika dilihat dari jenis penelitian maka penelitian termasuk dalam penelitian penjelasan (explanatory research) karena bertujuan untuk menjelaskan suatu hubungan antar variabel melalui pengujian suatu hipotesis (Ghozali, 2005:2). Jenis penelitian ini dipilih karena tujuan yang hendak dicapai mencakup usaha-usaha untuk menjelaskan bagaimana hubungan pengaruh yang terjadi diantara variabel yang diteliti. Hubungan yang diteliti merupakan hubungan kausal, yaitu hubungan yang bersifat sebab akibat (Sugiyono, 2012: 59) Jadi terdapat variabel bebas (variabel yang mempengaruhi) dan variabel terikat (variabel yang dipengaruhi). Dalam penelitian ini variabel terikat adalah niat menginap dari wisatawan $(\mathrm{Y})$ sedangkan varabel bebas adalah pengetahuan (X1) dan sikap kepada lingkungan (X2). Variabel penelitian seperti terlihat pada Tabel 1

Pembahasan dalam penelitian ini mencakup pengetahuan dan sikap kepada lingkungan terhadap niat menginap di hotel ramah lingkungan, sementara subjek dalam penelitian ini adalah konsumen yang merupakan wisatawan yang datang ke Bali yang mengetahui atau pernah mendengar tentang hotel ramah lingkungan

Tabel 1

Variabel Penelitian

\begin{tabular}{|c|c|c|c|}
\hline Variabel & $\begin{array}{l}\text { Jumlah } \\
\text { Indikator }\end{array}$ & Indikator & Sumber \\
\hline $\begin{array}{l}\text { Pengetahua } \\
\text { (X1) }\end{array}$ & 3 & $\begin{array}{l}\text { 1. Familiar dengan hotel yang } \\
\text { memiliki kebijakan } \\
\text { lingkungan } \\
\text { 2. Familiar dengan program } \\
\text { green hotel } \\
\text { 3. Familiar dengan label green } \\
\text { hotel }\end{array}$ & $\begin{array}{l}\text { Norazah Mohd } \\
\text { Suki \& Norbayah } \\
\text { Mohd Suki, } 2014\end{array}$ \\
\hline $\begin{array}{l}\text { Sikap } \\
\text { Lingkungan } \\
\text { (X2) }\end{array}$ & 3 & $\begin{array}{l}\text { 1. Menginap di green hotel } \\
\text { sangat baik } \\
\text { 2. Menginap di hotel sangat } \\
\text { diinginkan } \\
\text { 3. Menginap di hotel adalah hal } \\
\text { yang positif }\end{array}$ & $\begin{array}{c}\text { Norazah Mohd } \\
\text { Suki \& Norbayah } \\
\text { Mohd Suki, } 2014\end{array}$ \\
\hline $\begin{array}{l}\text { Niat Menginap } \\
\text { (Y) }\end{array}$ & 3 & $\begin{array}{l}\text { 1. Rela menginap di green } \\
\text { hotel selama perjalanan } \\
\text { 2. Merencanakan menginap di } \\
\text { green hotel selama } \\
\text { perjalanan } \\
\text { 3. Berusaha menginap di green } \\
\text { hotel selama perjalanan }\end{array}$ & $\begin{array}{c}\text { Norazah Mohd } \\
\text { Suki \& Norbayah } \\
\text { Mohd Suki, } 2014\end{array}$ \\
\hline
\end{tabular}

Sumber : Data diolah, 2017

Jenis data yang dipergunaklan dalam penelitian ini berdasarkan sifatnya adalah data kualitatif dan data kuantitatif. Data Kualitatif terdiri atas data yang tidak berupa angka-angka, hanya berupa penjelasan-penjelasan dan tidak dapat diukur dalam satuan hitung seperti penjelasan mengenai pengetahuan dan sikap terhadap lingkungan, sedangkan data kuantitatif merupakan data berupa angka dalam arti sebenarnya yang 


\section{National Conference of Creative Industry: \\ Sustainable Tourism Industry for Economic Development}

Universitas Bunda Mulia, Jakarta, 5-6 September 2018

e-ISSN No: 2622-7436

dapat dihitung. Data kuantitatif pada penelitian ini adalah data hasil penyebaran kuesioner kepada responden.

Sumber Data menggunakan data primer. Data primer bersumber dari objek yang diamati dan diteliti secara langsung dengan melakukan pengumpulan data kepada sampel yang telah ditentukan. Adapun data primer yang dibutuhkan untuk dianalisis dalam penelitian ini adalah data dari kuesioner yang disebarkan kepada wisatawan yang memiliki pengetahuan dan memiliki niat menginap di hotel ramah lingkungan.

Teknik pengambilan sampel dalam penelitian ini terdiri dari penentuan populasi dan pengambilan sampel sebagai berikut : populasi pada penelitian ini adalah wisatawan yang memiliki niat menginap di hotel ramah lingkungan. Berkaitan dengan fenomena pada latar belakang, maka sampel dalam penelitian ini bersifat non probability sampling karena semua elemen dalam populasi yang ada tidak memiliki kesempatan yang sama untuk dijadikan sampel. Metode non probability sampling digunakan karena jumlah populasi tidak dapat diidentifikasi dengan pasti. Metode non probability sampling yang digunakan adalah teknik purposive sampling, yaitu memilih anggota sampel yang disesuaikan dengan kriteria tertentu. Kriteria responden yang digunakan adalah wisatawan yang mengetahui tentang hotel ramah lingkungan. Ferdinand (2002:51) menyatakan untuk memperoleh hasil yang baik maka jumlah responden yang diambil untuk mengisi kuesioner adalah lima hingga sepuluh kali jumlah indikator. Pada penelitian ini terdapat 9 indikator, sehingga rentang ukuran sampel yang baik adalah $45 \leq \mathrm{n} \leq 90$. Berdasarkan rentangan tersebut, dengan mempertimbangkan sumber daya yang ada maka dalam penelitian ini ditentukan ukuran sampel sebanyak 90 orang. Jumlah tersebut dianggap telah mewakili populasi.

Teknik pengumpulan data menggunakan kuesioner dan studi dokumentasi. Teknik analisis data menggunakan data kuantitatif dengan menggunakan metode statistik regresi linier berganda. Teknik Analisis linier berganda bertujuan untuk mengetahui pengaruh variable independen, yaitu pengetahuan dan sikap lingkungan terhadap variabel dependen yaitu niat menginap di hotel ramah lingkungan

Hipotesis yang ingin dibuktikan dalam penelitian ini adalah:

1) H1 :Pengetahuan berpengaruh positif dan signifikan terhadap niat menginap di hotel ramah lingkungan

2) H2 :Sikap kepada lingkungan berpengaruh positif dan signifikan terhadap niat menginap di hotel ramah lingkungan

3) H3: Pengetahuan dan sikap kepada lingkungan berpengaruh positif dan signifikan terhadap niat menginap di hotel ramah lingkungan

\section{HASIL DAN PEMBAHASAN}

\section{Karakteristik Responden}

Berdasarkan hasil kuesioner terhadap 90 orang wisatawan menunjukkan karakteristik responden menurut jenis kelamin, usia, tingkat pendidikan terakhir, dan pekerjaan responden sebagai berikut : Berdasarkan jenis kelamin responden laki-laki mendominasi yaitu sebesar 54,4 \% dibandingkan dengan responden wanita sebesar 45,6 $\%$. Sedangkan berdasarkan kelompok usia, responden berusia 21 hingga usia 30 tahun memiliki persentase tertinggi, yaitu sebesar $50 \%$. Dilihat dari tingkat pendidikan, dapat diketahui bahwa tingkat pendidikan diploma yang paling banyak memberi jawaban dengan presentase $42,2 \%$, sedangkan berdasarkan jenis pekerjaan diperoleh data 
bahwa kelompok pegawai swasta yang paling banyak menjadi responden dengan persentase $42,2 \%$.

\section{Karakteristik Jawaban Responden}

Karakteristik jawaban responden berdasarkan kuesioner yang telah terkumpul dapat dikelompokkan menjadi karakteristik variabel menurut pengetahuan, sikap kepada lingkungan dan niat menginap di hotel ramah lingkungan.

1) Pengetahuan

Penilaian responden atas pernyataan-pernyataan mengenai pengetahuan dapat dideskripsikan pada Tabel 2 .

Tabel 2 Nilai Rata-rata Penilaian Responden Terhadap Pernyataan Pengetahuan

\begin{tabular}{|c|l|c|c|}
\hline No & \multicolumn{1}{|c|}{ Pernyataan } & $\begin{array}{c}\text { Rata-rata } \\
\text { skor }\end{array}$ & Keterangan \\
\hline 1. & $\begin{array}{l}\text { Dibandingkan dengan orang lain, saya familiar } \\
\text { dengan peraturan hotel ramah lingkungan }\end{array}$ & 3,86 & Baik \\
\hline 2 & $\begin{array}{l}\text { Dibandingkan dengan teman saya, saya } \\
\text { familiar dengan program hotel ramah } \\
\text { lingkungan }\end{array}$ & 3,76 & Baik \\
\hline 3. & $\begin{array}{l}\text { Dibandingkan dengan orang yang sudah sering } \\
\text { melakukan traveling, saya familiar dengan } \\
\text { brand } \text { hotel ramah lingkungan }\end{array}$ & 3,74 & Baik \\
\hline \multicolumn{1}{|c|}{ rata-rata } & 3,79 & Baik \\
\hline
\end{tabular}

Sumber : data diolah (2017)

Dari Tabel 2 tampak bahwa variabel pengetahuan rata-rata nilainya adalah 3,79 berada pada rentang nilai 3,41-4,20 dengan kategori baik. Nilai tertinggi terdapat pada butir pernyataan pertama dengan rata-rata 3,86 (baik). Sedangkan nilai terendah terdapat pada butir pernyataan ketiga dengan rata-rata 3,74 (baik).

2) Sikap Kepada Lingkungan

Penilaian responden atas pernyataan-pernyataan mengenai sikap kepada lingkungan dapat dideskripsikan pada Tabel 3

Tabel 3 Nilai Rata-rata Penilaian Responden Terhadap Pernyataan Sikap Kepada Lingkungan

\begin{tabular}{|c|l|c|c|}
\hline No & \multicolumn{1}{|c|}{ Pernyataan } & $\begin{array}{c}\text { Rata-rata } \\
\text { skor }\end{array}$ & Keterangan \\
\hline 1. & $\begin{array}{l}\text { Bagi saya, ketika mengunjungi suatu negara tinggal di } \\
\text { hotel ramah lingkungan adalah baik }\end{array}$ & 4,38 & Sangat Baik \\
\hline 2 & $\begin{array}{l}\text { Bagi saya, ketika mengunjungi suatu negara tinggal di } \\
\text { hotel ramah lingkungan adalah yang diinginkan }\end{array}$ & 4,24 & Sangat Baik \\
\hline 3. & $\begin{array}{l}\text { Ketika mengunjungi suatu negara tinggal di hotel ramah } \\
\text { lingkungan adalah positif }\end{array}$ & 4,42 & Sangat Baik \\
\hline \multicolumn{2}{|c|}{ rata-rata } & 4,35 & Sangat Baik \\
\hline
\end{tabular}


Sumber : data diolah (2017)

Dari Tabel 3 tampak bahwa variabel sikap kepada lingkungan rata-rata nilainya adalah 4,35 berada pada rentang nilai 4,21-5,00 dengan kategori sangat baik. Nilai tertinggi terdapat pada butir pernyataan ketiga dengan rata-rata 4,42 (sangat baik). Sedangkan nilai terendah terdapat pada butir pernyataan ketiga dengan rata-rata 4,24 (sangat baik).

3) Niat Menginap di Hotel Ramah Lingkungan

Penilaian responden atas pernyataan-pernyataan mengenai niat menginap di hotel ramah lingkungan dapat dideskripsikan pada Tabel 4

Tabel 4 Nilai Rata-rata Penilaian Responden

Terhadap Pernyataan Niat Menginap di Hotel Ramah Lingkungan

\begin{tabular}{|c|l|c|c|}
\hline No & \multicolumn{1}{|c|}{ Pernyataan } & $\begin{array}{c}\text { Rata-rata } \\
\text { skor }\end{array}$ & Keterangan \\
\hline 1. & $\begin{array}{l}\text { Saya ingin tinggal di green hotel ketika } \\
\text { melakukan suatu perjalanan }\end{array}$ & 4,20 & Baik \\
\hline 2 & $\begin{array}{l}\text { Saya merencanakan tinggal di green hotel } \\
\text { ketika melakukan suatu perjalanan }\end{array}$ & 4,13 & Baik \\
\hline 3. & $\begin{array}{l}\text { Saya berusaha untuk tinggal di green hotel } \\
\text { ketika melakukan suatu perjalanan }\end{array}$ & 4,01 & Baik \\
\hline \multicolumn{1}{|c|}{ rata-rata } & 4,11 & \\
\hline
\end{tabular}

Sumber : data diolah (2017)

Dari Tabel 4 tampak bahwa variabel niat menginap di hotel ramah lingkungan rata-rata nilainya adalah 4,11 berada pada rentang nilai 3,41-4,20 dengan kategori baik. Nilai tertinggi terdapat pada butir pernyataan pertama dengan rata-rata 4,20 (baik). Sedangkan nilai terendah terdapat pada butir pernyataan ketiga dengan rata-rata 4,01 (baik).

\section{Uji Validitas}

Pengujian validitas sebagai ukuran seberapa kuat suatu alat melakukan fungsi ukurnya. Berdasarkan Tabel 5, 6 dan 7 seluruh item pernyataan menunjukkan nilai $\mathrm{r}_{\text {hitung }}$ $\geq \mathrm{r}_{\text {standar }}(0,3)$ pada nilai signifikansi 5 persen, maka dapat dijelaskan bahwa seluruh indikator konstruk dalam penelitian ini adalah valid sehingga dapat digunakan sebagai instrumen penelitian.

Tabel 5 Hasil Uji Validitas Pengetahuan

\begin{tabular}{|c|c|c|c|c|}
\hline No. & Item Pertanyaan & r hitung & r standar & Keterangan \\
\hline 1. & X1.1 & 0,664 & 0,30 & r hitung > r standar ; Valid \\
\hline 2. & X1.2 & 0,742 & 0,30 & r hitung > r standar ; Valid \\
\hline 3. & X1.3 & 0,664 & 0,30 & r hitung > r standar ; Valid \\
\hline
\end{tabular}

Tabel 6 Hasil Uji Validitas Sikap

\begin{tabular}{|c|c|c|c|c|}
\hline No. & Item Pertanyaan & r hitung & r standar & Keterangan \\
\hline 1. & X2.1 & 0,636 & 0,30 & r hitung > r standar ; Valid \\
\hline
\end{tabular}




\begin{tabular}{|l|l|l|l|l|}
\hline 2. & $\mathrm{X} 2.2$ & 0,617 & 0,30 & r hitung > r standar ; Valid \\
\hline 3. & $\mathrm{X} 2.3$ & 0,662 & 0,30 & $\mathrm{r}$ hitung > r standar ; Valid \\
\hline
\end{tabular}

Tabel 7 Hasil Uji Validitas Niat Menginap

\begin{tabular}{|c|c|c|c|c|}
\hline No & Item Pertanyaan & r hitung & r standar & Keterangan \\
\hline 1. & Y1.1 & 0,597 & 0,30 & r hitung > r standar ; Valid \\
\hline 2. & Y2.2 & 0,713 & 0,30 & r hitung > r standar ; Valid \\
\hline 3. & Y2.3 & 0,723 & 0,30 & r hitung > r standar ; Valid \\
\hline
\end{tabular}

Uji Reliabilitas adalah mengukur konsistensi suatu instrumen, pada penelitian ini digunakan koefesien cronbach alpha yang menyatakan bahwa nilai instrumen dikatakan reliabel bila nilai cronbach alpha $\geq 0.6$. Hasil uji reliabilitas dapat dilihat pada Tabel 8 .

Tabel 8

Hasil Uji Reliabilitas

\begin{tabular}{|c|l|c|c|}
\hline No & \multicolumn{1}{|c|}{ Konstruk } & Cronbach Alpha & Keterangan \\
\hline 1 & Pengetahuan lingkungan & 0,828 & Reliabel \\
\hline 2 & Sikap pada lingkungan & 0,795 & Reliabel \\
\hline 3 & Niat Menginap & 0,882 & Reliabel \\
\hline
\end{tabular}

Berdasarkan Tabel 8 dapat diketahui bahwa cronbach alpha seluruh instrumen tersebut $>0,6$. Ini berarti bahwa hasil pengukuran dapat memberikan hasil yang konsisten apabila dilakukan pengukuran kembali terhadap subyek yang sama.

\section{Analisis Regresi Linear Berganda}

Analisis ini digunakan untuk mengetahui perubahan niat menginap di hotel ramah lingkungan yang dipengaruhi oleh pengetahuan dan sikap kepada lingkungan. Hasil analisis linier berganda dengan bantuan software IBM SPSS Statistic 20 dapat dilihat pada Tabel 9 seperti berikut :

\begin{tabular}{|c|c|c|c|c|c|c|c|}
\hline \multirow[b]{3}{*}{ Model } & \multicolumn{7}{|c|}{$\begin{array}{c}\text { Tabel } 9 \text { Hasil Analisis Regresi Linier Berganda } \\
\text { Coefficients }^{a}\end{array}$} \\
\hline & \multicolumn{2}{|c|}{$\begin{array}{l}\text { Unstandardized } \\
\text { Coefficients }\end{array}$} & \multirow{2}{*}{$\begin{array}{c}\text { Standardized } \\
\text { Coefficients } \\
\text { Beta } \\
\end{array}$} & \multirow[b]{2}{*}{$\mathrm{T}$} & \multirow[b]{2}{*}{ Sig. } & \multicolumn{2}{|c|}{$95.0 \%$ Confidence Interval for B } \\
\hline & $\mathrm{B}$ & Std. Error & & & & Lower Bound & Upper Bound \\
\hline (Constant) & 2.699 & 1.598 & & 1.690 & .095 & -.476 & 5.875 \\
\hline $\begin{array}{l}\text { Pengetahuan } \\
\text { lingkungan }\end{array}$ & .331 & .108 & .293 & 3.079 & .003 & .117 & .545 \\
\hline Sikap & .451 & .115 & .374 & 3.929 & .000 & .223 & .679 \\
\hline
\end{tabular}

a. Dependent Variable: Niat menginap

Sumber: data diolah (2017)

Dari tabel Coefficient yang ditunjukkan pada Tabel 9, diperoleh persamaan regresi berganda berikut:

$$
\mathrm{Y}=2,699+0,331 \mathrm{X}_{1}+0,451 \mathrm{X}_{2}+\mathrm{e}
$$




\section{National Conference of Creative Industry: Sustainable Tourism Industry for Economic Development}

Universitas Bunda Mulia, Jakarta, 5-6 September 2018 e-ISSN No: 2622-7436

Dari hasil persamaan yang diperoleh ini, maka dapat dijelaskan pola pengaruh pengetahuan $\left(\mathrm{X}_{1}\right)$ dan sikap pada lingkungan $\left(\mathrm{X}_{2}\right)$ terhadap niat menginap di hotel ramah lingkungan (Y) sebagai berikut:

a. Nilai konstanta sebesar 2,699 menunjukkan bahwa niat menginap di hotel ramah lingkungan $(\mathrm{Y})$ akan bernilai 2,699 poin apabila variabel pengetahuan $\left(\mathrm{X}_{1}\right)$ dan sikap kepada lingkungan $\left(\mathrm{X}_{2}\right)$ besarnya sama dengan 0 .

b. Nilai koefisien pengetahuan lingkungan $\left(\mathrm{X}_{1}\right)$ sebesar 0,331 menunjukkan bahwa niat menginap di hotel ramah lingkungan (Y) akan meningkat sebesar 0,331 poin apabila variabel pengetahuan $\left(\mathrm{X}_{1}\right)$ mengalami kenaikan satu satuan. Nilai koefisien yang positif menunjukkan bahwa pengetahuan $\left(\mathrm{X}_{1}\right)$ bernilai searah dengan niat menginap di hotel ramah lingkungan (Y). Hal ini berarti bila semakin luas pengetahuan lingkungan, maka niat menginap di hotel ramah lingkungan pun juga akan meningkat.

Nilai koefisien sikap kepada lingkungan $\left(\mathrm{X}_{2}\right)$ sebesar 0,451 menunjukkan bahwa niat menginap di hotel ramah lingkungan $(\mathrm{Y})$ akan meningkat sebesar 0,451 poin apabila variabel sikap kepada lingkungan $\left(\mathrm{X}_{2}\right)$ mengalami kenaikan satu satuan. Nilai koefisien yang positif menunjukkan bahwa sikap kepada lingkungan $\left(\mathrm{X}_{2}\right)$ bernilai searah dengan niat menginap di hotel ramah lingkungan (Y). Hal ini berarti bila sikap kepada lingkungan meningkat, maka niat menginap di hotel ramah lingkunganpun akan meningkat.

\section{Uji T (t-test)}

Uji t (t-test) dilakukan untuk mengetahui signifikan atau tidaknya pengaruh masing-masing variabel bebas yaitu pengetahuan dan sikap pada lingkungan secara parsial terhadap variabel terikat yaitu niat menginap di hotel ramah lingkungan. Hasil uji t ditunjukkan pada Tabel 10 sebagai berikut:

\begin{tabular}{|c|c|c|c|c|c|c|c|}
\hline \multirow[b]{3}{*}{ Model } & \multicolumn{6}{|c|}{$\begin{array}{c}\text { Tabel } 10 \text { Hasil Analisis Uji T } \\
\text { tCoefficients }^{\text {a }}\end{array}$} & \\
\hline & \multicolumn{2}{|c|}{$\begin{array}{l}\text { Unstandardized } \\
\text { Coefficients }\end{array}$} & \multirow{2}{*}{$\begin{array}{c}\text { Standardized } \\
\text { Coefficients } \\
\text { Beta } \\
\end{array}$} & \multirow[b]{2}{*}{$\mathrm{t}$} & \multirow[b]{2}{*}{ Sig. } & \multicolumn{2}{|c|}{$95.0 \%$ Confidence Interval for B } \\
\hline & $\mathrm{B}$ & Std. Error & & & & Lower Bound & Upper Bound \\
\hline (Constant) & 2.699 & 1.598 & & 1.690 & .095 & -.476 & 5.875 \\
\hline $\begin{array}{l}\text { Pengetahuan } \\
\text { lingkungan }\end{array}$ & .331 & .108 & .293 & 3.079 & .003 & .117 & .545 \\
\hline Sikap & .451 & .115 & .374 & 3.929 & .000 & .223 & .679 \\
\hline
\end{tabular}

a. Dependent Variable: Niat menginap

Sumber: data diolah (2017)

Hasil uji $\mathrm{t}$ variabel pengetahuan terhadap niat menginap di hotel ramah lingkungan menunjukkan nilai $\mathrm{t}_{\text {-hitung }}>\mathrm{t}_{\text {-tabel }}=(3,079>1,671)$ maka Ho ditolak, di mana hipotesis yang menyatakan bahwa diduga terdapat pengaruh yang positif dan signifikan antara pengetahuan $\left(\mathrm{X}_{1}\right)$ terhadap niat menginap di hotel ramah lingkungan $(\mathrm{Y})$ teruji kebenarannya

Hasil uji t variabel sikap pada lingkungan terhadap niat menginap di hotel ramah lingkungan menunjukkan nilai $t_{\text {-hitung }}>\mathrm{t}_{\text {-tabel }}=(3,929>1,671)$ maka Ho ditolak, di mana hipotesis yang menyatakan bahwa diduga terdapat pengaruh yang positif dan signifikan 
antara pengetahuan $\left(\mathrm{X}_{1}\right)$ terhadap niat menginap di hotel ramah lingkungan $(\mathrm{Y})$ teruji kebenarannya.

\section{Uji F}

Uji $\mathrm{F}$ berguna untuk mengetahui tingkat signifikansi dan pengaruh variabel bebas secara simultan atau bersama-sama terhadap variabel terikat. Hasil Pengujian seperti terlihat pada Tabel 11 berikut ini :

\section{Tabel 11 Hasil Analisis Uji F \\ ANOVA $^{\mathrm{a}}$}

\begin{tabular}{l|r|r|r|r|r} 
Model & Sum of Squares & Df & Mean Square & F & \multicolumn{1}{c}{ Sig. } \\
\hline 1 & 137.158 & 2 & 68.579 & 18.577 & $.000^{\mathrm{b}}$ \\
\hline Regression & 321.164 & 87 & 3.692 & & \\
\hline Residual & 458.322 & 89 & & & \\
\hline Total & & & & \\
\hline
\end{tabular}

a. Dependent Variable: Niatmenginap

b. Predictors: (Constant), Sikap, Pengetahuan lingkungan

Sumber: data diolah (2017)

Hasil uji menunjukkan nilai $\mathrm{F}_{\text {-hitung }}>\mathrm{F}_{\text {-tabel }}=(18,577>3,09)$ dimana hipotesis yang menyatakan bahwa diduga terdapat pengaruh yang positif dan signifikan secara simultan antara pengetahuan $\left(\mathrm{X}_{1}\right)$ dan sikap kepada lingkungan $\left(\mathrm{X}_{2}\right)$ terhadap niat menginap di hotel ramah lingkungan $(\mathrm{Y})$.

\section{Analisis Koefisien Determinasi $\left(\mathbf{R}^{2)}\right.$}

Analisis ini digunakan untuk mengetahui besar pengaruh antara pengetahuan $\left(\mathrm{X}_{1}\right)$ dan sikap kepada lingkungan $\left(\mathrm{X}_{2}\right)$ terhadap niat menginap di hotel ramah lingkungan(Y) yang dinyatakan dalam persentase. Koefisien determinasi dapat dilihat pada Tabel 12.

\section{Tabel 12 Koefisien Determinasi}

\begin{tabular}{|c|c|c|c|c|c|c|c|c|c|}
\hline \multirow[b]{3}{*}{ Model } & \multirow[b]{3}{*}{$\mathrm{R}$} & \multicolumn{7}{|c|}{ Model Summary } & \multirow{3}{*}{$\begin{array}{c}\text { Sig. F } \\
\text { Change }\end{array}$} \\
\hline & & \multirow[b]{2}{*}{$\begin{array}{c}\text { R } \\
\text { Square }\end{array}$} & \multirow[b]{2}{*}{$\begin{array}{l}\text { Adjusted } \\
\text { R Square } \\
\end{array}$} & \multirow{2}{*}{$\begin{array}{c}\begin{array}{c}\text { Std. Error of } \\
\text { the }\end{array} \\
\text { Estimate }\end{array}$} & \multicolumn{4}{|c|}{ Change Statistics } & \\
\hline & & & & & $\begin{array}{c}\text { R Square } \\
\text { Change }\end{array}$ & $\begin{array}{c}\mathrm{F} \\
\text { Change }\end{array}$ & df1 & $\mathrm{df} 2$ & \\
\hline 1 & $.547^{\mathrm{a}}$ & .299 & .283 & 1.92134 & .299 & 18.577 & 2 & 87 & .000 \\
\hline
\end{tabular}

a. Predictors: (Constant), Sikap, Pengetahuan lingkungan

b. Dependent Variable: Niatmenginap

Sumber: data diolah (2017)

Berdasarkan Tabel 12 dapat diketahui nilai $\mathrm{R}^{2}$ sebesar 0,299 . Nilai $\mathrm{R}^{2}$ yang diperoleh dari analisis regresi linear berganda disebut sebagai koefisien determinasi, yang menunjukkan seberapa besar pengaruh variabel independen pengetahuan $\left(\mathrm{X}_{1}\right)$ dan sikap kepada lingkungan $\left(\mathrm{X}_{2}\right)$ secara simultan terhadap variabel dependen niat menginap di hotel ramah lingkungan $(\mathrm{Y})$. Pengetahuan $\left(\mathrm{X}_{1}\right)$ dan sikap kepada 
lingkungan $\left(\mathrm{X}_{2}\right)$ mempengaruhi niat menginap di hotel ramah lingkungan $(\mathrm{Y})$ sebesar $29,9 \%$. Artinya, $70,1 \%$ sisanya dipengaruhi oleh faktor-faktor lain di luar model regresi ini.

Melalui pengolahan data penelitian dengan bantuan software IBM SPSS Statistic 20 juga dapat diketahui nilai standardized coefficient beta yang digunakan untuk mengetahui kontribusi nyata dari masing-masing variabel bebas terhadap variabel terikat. Kontribusi nyata dari masing-masing variabel bebas disajikan pada Tabel 13 berikut.

Tabel 13 Nilai Standardized Coefficient Beta

\section{Coefficients $^{\mathrm{a}}$}

\begin{tabular}{|c|c|c|c|c|c|c|c|c|}
\hline \multirow{2}{*}{\multicolumn{2}{|c|}{ Model }} & \multicolumn{2}{|c|}{$\begin{array}{c}\text { Unstandardized } \\
\text { Coefficients }\end{array}$} & \multirow{2}{*}{$\begin{array}{c}\text { Standardize } \\
\mathrm{d} \\
\text { Coefficients } \\
\text { Beta } \\
\end{array}$} & \multirow[b]{2}{*}{$T$} & \multirow[b]{2}{*}{ Sig. } & \multicolumn{2}{|c|}{$\begin{array}{l}95.0 \% \text { Confidence } \\
\text { Interval for B }\end{array}$} \\
\hline & & $B$ & Std. Error & & & & $\begin{array}{l}\text { Lower } \\
\text { Bound }\end{array}$ & $\begin{array}{l}\text { Upper } \\
\text { Bound } \\
\end{array}$ \\
\hline \multirow[t]{3}{*}{1} & (Constant) & 2.699 & 1.598 & & 1.690 & .095 & -.476 & 5.875 \\
\hline & $\begin{array}{l}\text { Pengetahu } \\
\text { an } \\
\text { lingkungan }\end{array}$ & .331 & .108 & .293 & 3.079 & .003 & .117 & .545 \\
\hline & Sikap & .451 & .115 & .374 & 3.929 & .000 & .223 & .679 \\
\hline
\end{tabular}

a. Dependent Variable: Niatmenginap

Sumber:: data diolah (2017)

Berdasarkan Tabel 13 dapat diketahui bahwa setiap variabel bebas mempunyai kontribusi yang berbeda dalam membentuk niat menginap di hotel ramah lingkungan. Pengetahuan lingkungan dengan nilai 0,293 atau $8,5 \%\left(0,293^{2} \times 100 \%\right)$ mempunyai kontribusi dalam membentuk niat menginap di hotel ramah lingkungan

\section{KESIMPULAN DAN IMPLIKASI}

Pengetahuan berpengaruh positif dan signifikan terhadap niat menginap di hotel ramah lingkungan artinya semaikin luas pengetahuan seseorang mengenai lingkungan maka semakin tinggi niat menginap di hotel ramah lingkungan.

Sikap kepada lingkungan berpengaruh positif dan signifikan terhadap niat menginap di hotel ramah lingkungan artinya semakin positif sikap kepada lingkungan maka samakin tinggi niat menginap di hotel ramah lingkungan.

Pengetahuan dan sikap pada lingkungan secara simultan berpengaruh positif dan signifikan terhadap niat menginap di hotel ramah lingkungan artinya samakin luas pengetahuan lingkungan dan semakin positif sikap kepada lingkungan maka secara bersama sama akan meningkatkan niat menginap di hotel ramah lingkungan.

Tren pengembangan hotel ramah lingkungan menunjukkan hasil yang positif signifikan artinya wisatawan dalam mengunjungi suatu destinasi wisata sudah mempertimbangkan untuk menginap di hotel ramah lingkungan, untuk itu 


\section{National Conference of Creative Industry: \\ Sustainable Tourism Industry for Economic Development}

Universitas Bunda Mulia, Jakarta, 5-6 September 2018 e-ISSN No: 2622-7436

pengembangan konsep hotel yang ramah lingkungan perlu terus ditingkatkan demi keberlangsungan lingkungan (sustainable)

Manajemen hotel perlu lebih gencar dalam memperkenalkan produk ramah lingkungan atau menampilkan brand ramah lingkungan yang sudah diraih, karena wisatawan akan mempertimbangkan dan memilih suatu destinasi/hotel berdasarkan produk-produk ramah lingkungan yang ditawarkan. Wisatawan bahkan dapat memilih hotel yang diinginkan ketika mereka masih berada di negaranya.

\section{DAFTAR PUSTAKA}

Aman, A. H. L., Harun, A., \& Hussein, Z. (2012). The influence of environmental knowledge and concern on green purchase intention the role of attitude as a mediating variable. British Journal of Art and Social Sciences, 7 (2), 145 - 167

Engel, J.F. et.al., 1994, Consumer Behavior, Jilid 1, Alih Bahasa Budiyanto, Penerbit : Binarupa Aksara, Jakarta. Penerbit : Erlangga, Jakarta

Ferdinand, Agusty. 2002. Structural Equation Modelling dalam Penelitian Manajemen. Badan Penerbit Universitas Diponogoro. Semarang

Ghozali,I. 2005. Aplikasi :Analisis Multivariate dengan Program SPSS. Edisi 3. Semarang: Badan Penerbit Universitas Diponogoro

Haryadi, Rudi. 2009. Pengaruh Strategi Green Marketing Terhadap Pilihan Konsumen Melalui Pendekatan Marketing Mix. Program Magister Manajemen. Universitas Diponegoro, Semarang

Kotler, Philip dan Gary Amstrong. 2007. Manajemen PT Indeks.. Jakarta

Kotler, Philip dan Gary Amstrong. 2008. Prinsip-Prinsip Pemasaran. Erlangga. Jakarta

Lin, Nan Hong and Bih Sya Lin. 2007. The Effect of Brand Image and Product Knowledge on Purchase Intention Moderated by Price Discount. Journal of International Management Studies 1 (13): 121-132

Norazah Mohd Suki \& Norbayah Mohd Suki. 2015. Consumers' Environmental Behavior Towards Staying at a Green Hotel. Moderation of Green Hotel Knowledge.Management Of Environmental Quyality An International Journal. Vol 26 No.1. 2015 pp.103-107

Sugiyono. 2012. Metode Penelitian Kuantitatif Kualitatif dan $R \& B$. Bandung: Alfabeta

Sulastiyono, Agus. 2011. Manajemen Penyelenggaraan Hotel. Bandung. Alfabeta

Sulis Purwanto, 2016. Pariwisata Indonesia. https:// sulispurwanto..../dampakperkembangan-pariwisata. Diakses 25 Juli 2017 


\section{National Conference of Creative Industry: \\ Sustainable Tourism Industry for Economic Development}

Universitas Bunda Mulia, Jakarta, 5-6 September 2018 e-ISSN No: 2622-7436

Sumarsono.,dan Yayat Giyatno. 2012. Analisis Sikap dan Pengetahuan Konsumen terhadap Ecolabelling serta Pengaruhnya pada Keputusan Pembelian Produk Ramah Lingkungan. PERFORMANCE, 15 (1), h: 70-85

Suprapti, N.W.S. 2010. Perilaku Konsumen : Pemahaman Dasar dan Aplikasinya dalam Strategi Pemasaran. Bali: Universitas Udayana Bali

Trihatmojo,M. Eco friendly Hotel. maharagtri.tumblr.com/post/45335013371/ecofriendly-hotel

Ying,A.N. 2015. Tourism Development and Ecological Environment Protection. Journal of Lanscape Research.pp.43-44

\section{BIODATA PENULIS}

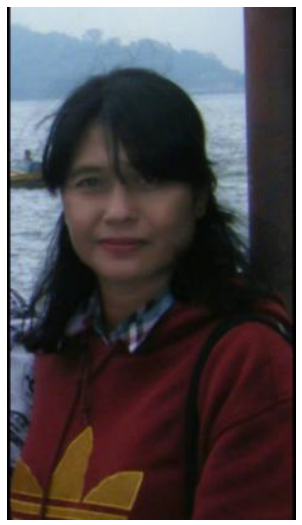

Ir. Ida Ayu Kalpikawati,M.Si, menyelesaikan pendidikan S1 pada tahun 1991 pada Program Studi Teknologi Pertanian Universitas Udayana. Sejak Tahun 1993 menjadi dosen tetap di Sekolah Tinggi Pariwisata Nusa Dua Bali mengajar mata kuliah Hygiene Sanitasi dan Keselamatan Kerja serta Pengetahuan Gizi. Pada tahun 2004 melanjutkan studi S2 di Program Studi Ilmu Lingkungan Universitas Udayana dan selesai di tahun 2007. Kemudian mengajar mata kuliah Manajemen Lingkungan. Pernah menjadi editor pada Jurnal Gastronomi Indonesia dan pada tahun 2017 sampai sekarang, ikut bergabung dengan Tim THK Bali (Tri Hita Karana) sebagai asesor di bidang Palemahan. 